\title{
A coastal nature reserve in Malaysia
}

\author{
G.W.H. Davison, M. Akhir Othman, C. Prentice and J. Howes
}

\begin{abstract}
A nature reserve is being developed at Kuala Selangor on the west coast of Peninsular Malaysia. It is important as the core area of a major belt of mangrove forest and intertidal mudflats, an ecosystem poorly represented in South East Asian reserves. The concept, as well as its management by a non-governmental organization, are unique in the region.
\end{abstract}

There are 107,255 ha of mangroves in forest reserves in Peninsular Malaysia (Anon., 1987), about 96 per cent lying on the west coast (Tang et al., 1980). The natural values of mangroves have been well documented (Macnae, 1974; Saenger et al., 1981). Under natural conditions they act as seaward barriers against coastal erosion and aid in stabilizing the coastline. Mangroves are of great importance to coastal fisheries: it is estimated that 42 per cent of west coast landings comprise mangrove-associated species (Jothy, 1984). Fishing interests can be successfully combined with management for sustainable commercial forestry, as at the Matang Forest Reserve in Perak, which produces timber revenue up to US $\$ 9$ million annually (Haron and Cheah, 1979), and prawn and cockle landings of up to US $\$ 30$ million annually (Ong, 1982). More than 50 direct uses of mangrove are recognized by Saenger et al. (1981) including firewood, charcoal, construction materials, textiles, food and beverages.

Mangrove forests and mudflats on the west coast of Peninsular Malaysia are a crucial link in the East Palaearctic migration route of many waders, and their international importance has been demonstrated through the work of the Asian Wetland Bureau (for example, Parish and Wells, 1984, 1985; Silvius et al., 1987). Internationally significant sites include Kuala Gula at the northern end of the Matang Forest Reserve, Perak, and Pulau Tengah off the Selangor coast. A third 138 centres on Kuala Selangor, the mouth of Selangor state's largest river, extending several kilometres north and south (Figure 1).

Kuala Selangor, because of its mangrove forests, mudflats and easy access from the capital city Kuala Lumpur, has been a study site for ornithologists for many years. Forest clearance on

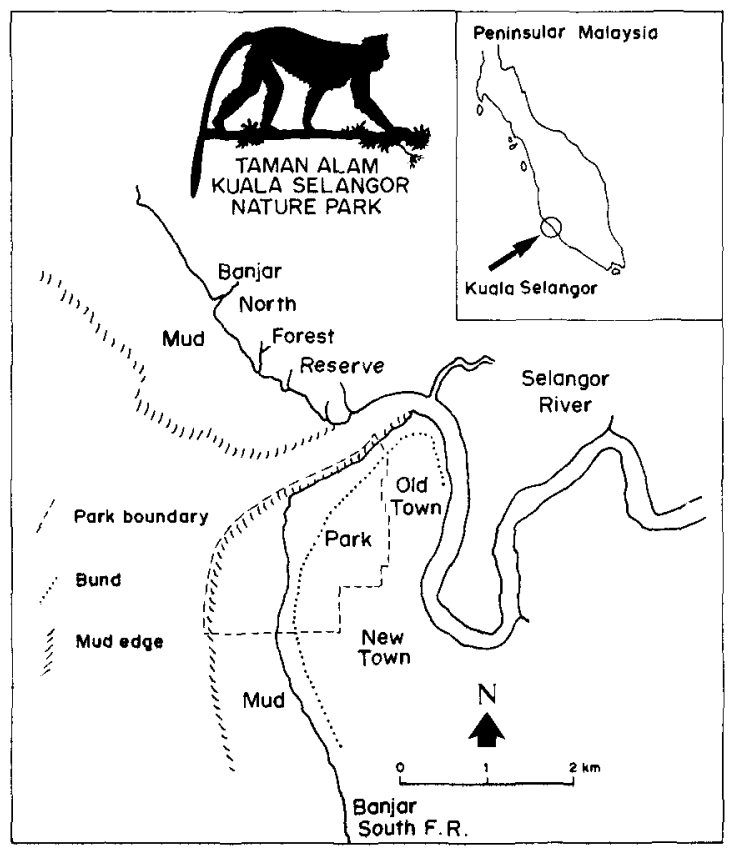

Figure 1. Location map of the Kuala Selangor Nature Park. Oryx Vol 23 No 3, July 1989 
the landward side in the early 1970 s to create evaporational salt pans proved uneconomic, but provided open ground, which came to be used as a wader roosting area when high tides covered the mudflats. The salt pans have been used as a ringing site by the University of Malaya Bird Ringing Project, and 8000 waders had been ringed there by 1983 (Parish and Wells, 1984).

As part of the new state developments, the Selangor State Government planned a new township in place of the salt pans. Further land was cleared prior to construction, which was under way by 1986 and should be complete by 1991. It was clear that this would remove what had become a major roost site for waders on migration, and at the same time place heavy pressures on the adjacent remaining mangroves and landward vegetation.

\section{Importance of the site}

Kuala Selangor's importance for conservation is partly as a link in the migratory chain through South East Asia. Between 60,000 and 120,000 waders are estimated to pass along the Selangor coast each year (Silvius et al., 1987), with a peak daily total of over 8000 birds recorded on the new town roost site (Asian Wetland Bureau, unpublished data). Some 30 species have been recorded at the roost, including the internationally endangered spoonbilled sandpiper Eurynorhynchus pygmaeus and Nordmann's greenshank Tringa guttifer. Lesser adjutant storks Leptoptilos javanicus are regular within the mangrove, and just south of the estuary is a breeding colony of grey herons Ardea cinerea, the only one known in Peninsular Malaysia.

Kuala Selangor is famous for its silvered leafmonkeys Presbytis cristata, studied by Bernstein (1968) and Wolf (1981). These live at high density within the mangrove and sub-coastal vegetation. At least six troops enter the town and the park-like Malawati Hill, which houses an eighteenth century fort and the mausoleum of Selangor sultans. Nearby the mangroves are inhabited by the butterfly Danaus affinis, rare in Malaysia though commoner in some neighbouring countries; its local food plant Ischnostemma selangorensis (Asclepiadaceae) is similarly restricted to a few localities on the west coast. This part of the coast is important to fisheries. The estuary holds one of the state's largest beds of cockles Anadara granosa (532 ha), a major source of local income.

Increasing human pressures from urban development would have major impacts upon these faunal and floristic elements, and indeed the pumping of sand from the estuary bed to fill the new town site killed a strip of mangrove a 100 metres wide. Construction of a bund by the Department of Irrigation and Drainage has altered tidal influences, with gradual drying of the landward area and replacement of the original mangrove trees by secondary species.

\section{Nature park planned}

In December 1986, members of the Malayan Nature Society and Asian Wetland Bureau (then Interwader) visited Kuala Selangor and noted the potential for a coastal reserve there. They proposed to the Selangor State Government that all remaining vegetation between the old and new towns be designated a nature park instead of the planned alternatives, a golf course, marina or prawn ponds. In May 1987 the State Executive Council earmarked 260 ha for the park, and the Malayan Nature Society was granted US $\$$ 40,000 for its initial development by September 1987. A committee of scientists from the Malayan Nature Society was set up, with invited representatives from the Asian Wetland Bureau and World Wide Fund for Nature (Malaysia).

The Society was thus taking on a development and management role, and its short term commitments were to complete a shallow lake system, trails, observation hides, car park and public exhibition within four months.

The rationale for lake construction was that bare islands within a lake would provide an alternative roosting site for waders at high tide, once construction of the new town had displaced them. Lakes were planned inland of the bund, where tidal influences had already been disrupted, where exotic tree species were invading the former mangrove habitat, and where the vegetation as a whole had become choked by creepers and the mangrove fern Acrostichum aureum.

The lake system covers 6 ha and consists of four 


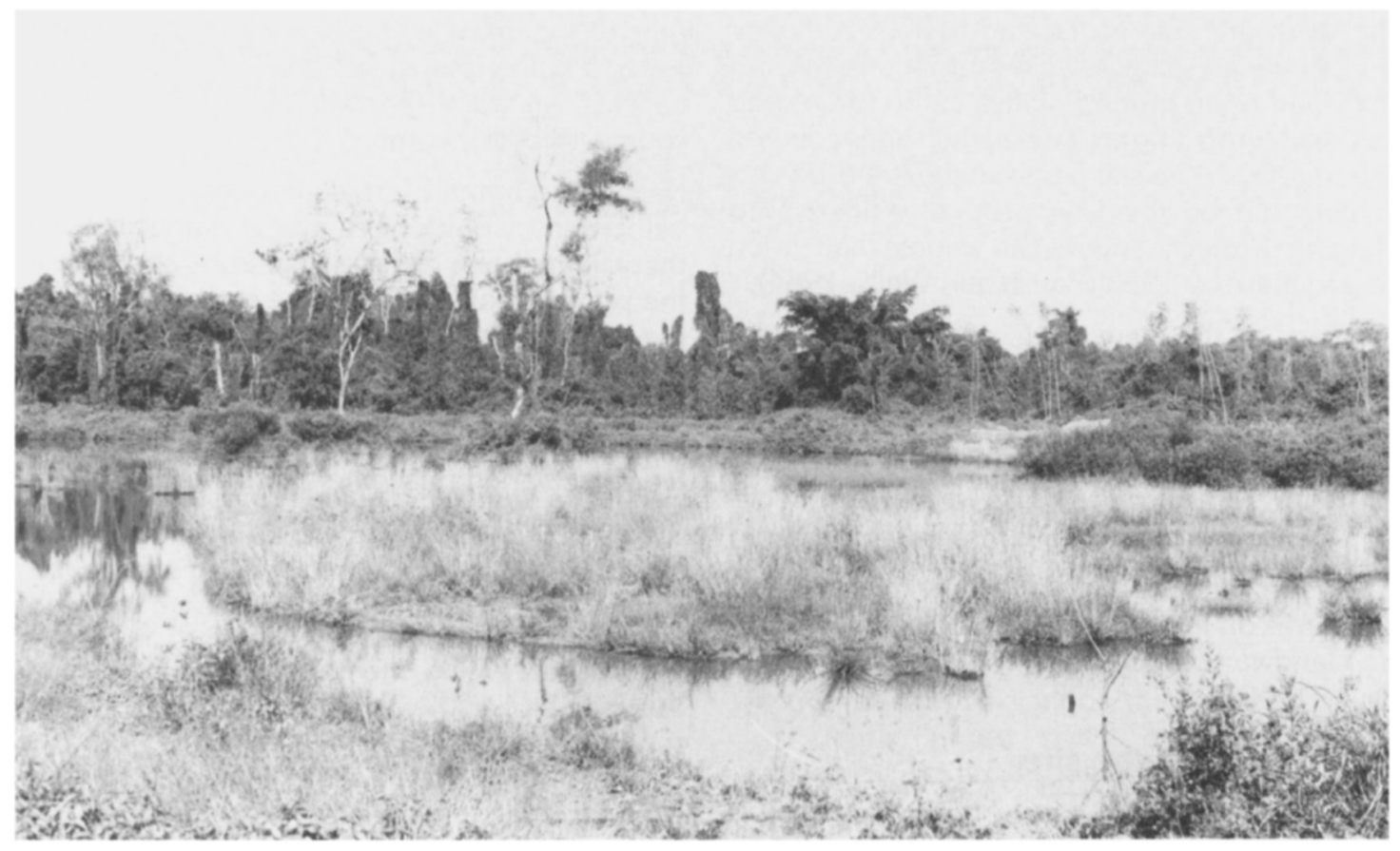

The new lake system, backed by degraded mangroves.

shallow interconnected lakes, each with a perimeter channel $1-1.5 \mathrm{~m}$ deep to prevent access by man and stray dogs. Most of the remaining water area is less than $0.3 \mathrm{~m}$ deep. Islands were constructed of spoil, covered by heavy duty polyvinyl plastic and by shell grit. More spoil was used up in surfacing an access road for maintenance. The favourable soil type has not led to acid sulphate conditions in the lake, which was filled by pumping from an adjacent Irrigation Department canal.

Two hides were constructed, looking out over different parts of the lake system, each accommodating up to 10 visitors, and approaches to the hides were hidden by palm thatch screens. The winding access road, closed to all but maintenance vehicles, acts as a nature trail flanked by mangrove trees such as Rhizophora mucronata, Bruguiera cylindrica and Avicennia officinalis, with their interesting adaptations such as stilt roots and pneumatophores. There are fig trees with aerial roots, the mounds of mud lobsters Thalassina anomala, and opportunities for bird and monkey watching. 140
Volunteer help from the Society members helped raise interest in the project. An engineering assistant was employed for three months. Other expertise was provided by Society members including staff of universities, government departments and research institutes. Approximately 90 per cent of expenditure was on actual costs of materials and construction. Administrative costs were borne by the Society.

\section{Current developments}

The Kuala Selangor Nature Park was opened in September 1987, before its legal status was fully resolved. It is now being gazetted as a town park under the Local Government Act 1976. The adjacent Banjar North and Banjar South mangrove forest reserves (Figure 1) are in the process of being declared forest sanctuaries for wildlife, under the National Forestry Act 1984. This is of crucial importance to the value of the nature park, as the centre of an integrated coastal conservation area, which will not only provide an educational and recreational resource, but will 
also protect the fisheries and the indigenous flora and fauna of the area.

Over 130 species of birds have been recorded from Banjar North and Banjar South forest reserves and the adjacent mudflats; by June 1988 over 80 had been seen within the section of the park immediately surrounding the lake. Smoothcoated otters Lutra perspicillata use the lake regularly, with 11 seen in the largest group. Increasing numbers of birds have begun to use shallow water areas, although the present trial freshwater regime is attracting few waders to feed in the lakes. As building of the new town continues, much larger numbers of waders are expected to utilize the lakes for roosting.

Plans for the immediate future include a permanent visitor centre with audio-visual facilities and exhibition; a boardwalk through the mangroves to the seaward edge; further hides near the lakes; and upgrading of the lake and island system. A tree planting scheme is under way using local species important to wildlife.

This is the first ever project in South East Asia to create de novo a lake for wildlife, the nearest parallel being at Mai Po in Hong Kong. It is the first managed nature reserve in Malaysia, in the sense that major habitat components such as water level and salinity can be controlled. It is also the first time that a Malaysian non-governmental organization has developed an area specifically for nature conservation with financial support from the government.

This, within 12 months of the park's conception, is a surprising and welcome degree of conservation success. Various problems exist, such as the rate of plant growth on islands, control of water level, and casual wood cutting in one part of the park. Plans are in hand to counteract these problems, and events so far are an encouraging pointer to the long-term conservation of a small but internationally important site.

\section{Acknowledgments}

The authors are indebted to all those involved in the establishment of the Kuala Selangor Nature Park, especially to En. Jabbari Ahmad and to Alison Blakelock, as well as to mem- bers and staff of the Malayan Nature Society and the Asian Wetland Bureau. Financial and administrative support from the Selangor State Government and from the Kuala Selangor District Office and Town Board has been invaluable.

\section{References}

Anon. 1987. Annual Report on Forestry in Peninsular Malaysia. Forestry Dept. Headquarters, Ministry of Primary Industries, Kuala Lumpur.

Bernstein, I.S. 1968. The lutong of Kuala Selangor. Behaviour, 32, 1-16.

Haron Hj. Abu Hassan and Cheah, L.C. 1979. Sustained yield management of the mangrove forest of Peninsular Malaysia with special reference to the Matang mangroves. Paper presented at 7 th Malaysian Forestry Conference, Penang, 24-28 September 1979.

Jothy, A.A. 1984. Capture fisheries and the mangrove ecosystem. In Proceedings of the workshop on productivity of the mangrove ecosystem: management implications (eds J.E. Ong and W.K. Gong). Universiti Sains Malaysia, Penang.

Macnae, W. 1974. Mangrove forests and fisheries. FAO/ UNDP Indian Ocean Fishery Programme, IOFC/DEV 74/ 34, pp. 35 .

Ong, J.E. 1982. Mangroves and aquaculture. Ambio. 2, 252--257.

Parish, D. and Wells, D.R. 1984. Interwader'83 Report. Interwader Publication No. 1, Kuala Lumpur.

Parish, D. and Wells, D.R. 1985. Interwader (East Asia/ Pacific Shorebird Study Programme) '84 Report. Interwader Publication No. 2, Kuala Lumpur.

Saenger, P., Hegerl, E.J. and Davie, J.D.S. (eds). 1981. First report on the global status of mangrove ecosystems. IUCN Commission on Ecology, Australia.

Silvius, M.J., Chan, H.T. and Shamsudin Ibrahim. 1987 Evaluation of wetlands of the west coast of Peninsular Malaysia and their importance for natural resource conservation. World Wildlife Fund (Malaysia), Kuala Lumpur.

Tang, H.T., Haron Hj. Abu Hassan and Cheah, E.K. 1980. Mangrove forests of Peninsular Malaysia - a review of management and research objectives and priorities. Asian Symposium on the Mangrove Environment, University of Malaya, Kuala Lumpur.

Wolf, K. 1981. Social behaviour of silvered leaf monkeys at Kuala Selangor. Ph.D. thesis, Yale, Connecticutt.

G.W.H. Davison, Malayan Nature Society. PO Box 10750 , 50724 Kuala Lumpur, Malaysia.

M. Akhir Othman, Malayan Nature Society, PO Box 10750. 50724 Kuala Lumpur, Malaysia.

C. Prentice, Asian Wetland Bureau, Insitute of Advanced Studies, University of Malaya, 59100 Kuala Lumpur. Malaysia.

J. Howes, Asian Wetland Bureau, Institute of Advanced Studies, University of Malaya, 59100 Kuala Lumpur, Malaysia. 